\title{
The effect of music on weight gain of preterm infants older than 32 weeks: a randomized clinical trial
}

\author{
Efeito da música sobre o ganho de peso de prematuros maiores de 32 semanas: ensaio \\ clínico randomizado
}

Efecto de la música sobre la ganancia de peso en prematuros mayores que 32 semanas hospitalizados en el Programa Madre-Canguro: ensayo clínico randomizado

Flávia Maria L. Auto ${ }^{1}$ Olga Maria S. Amancio², Fernanda de Córdoba Lanza ${ }^{3}$

\section{ABSTRACT}

Objective: To evaluate the effect of recorded music with multimodal stimulation on the weight gain of preterm infants included in the Kangaroo-Mother Program.

Methods: Randomized clinical trial with 61 premature infants, of both sexes, with postconceptional age greater or equal to 32 weeks and at least ten days of life, without detected abnormalities in the visual and hearing systems, and hospitalized in the Kangaroo-Mother Unit. Patients were randomized in two groups: of 31 preterm infants received multimodal stimulation with music daily, for seven days; 30 preterm infants received only multimodal stimulation. The following characteristics were evaluated: weight gain, energy consumption, heart rate and respiratory rate, stress signs and feeding method. Comparison between groups was made by Student's t-test, Mann Whitney test and chi-square test, being significant $p<0.05$.

Results: The two groups did not present significant differences in relation to the feeding method and energy consumption $(p=0.46)$; however, weight gain was greater in the Experimental Group $(p=0.002)$, which also presented better stability in cardiac and respiratory rates $(p<0.001)$ and a significant reduction of stress signs ( $p=0.007$ ), compared with the Control Group.

Conclusions: The recorded music with multimodal stimulation is associated with a greater gain in body weight of hospitalized preterm infants as well as presents a positive influence on vital and stress signs (Clinical Trials Registry - UTN: U1111-1153-9301).

Instituição: Maternidade-Escola Santa Mônica, Maceió, AL, Brasil ${ }^{1}$ Mestre em Ciências pela Universidade Federal de São Paulo (Unifesp); Fisioterapeuta do Hospital Universitário da Universidade Federal de Alagoas (UFAL), Maceió, AL, Brasil

${ }^{2}$ Professora-Associada Livre-Docente do Departamento de Pediatria da Escola Paulista de Medicina da Unifesp, São Paulo, SP, Brasil

${ }^{3}$ Doutora em Ciências pela Unifesp; Professora da Universidade Nove de Julho, São Paulo, SP, Brasil
Key-words: music; body weight; infant, premature; combined modality therapy.

\section{RESUMO}

Objetivo: Avaliar o efeito da música gravada com estimulação multimodal sobre o ganho de peso de prematuros incluídos no Programa Mãe-Canguru.

Métodos: Ensaio clínico randomizado com 61 prematuros, de ambos os sexos, com idade pós-concepcional maior ou igual a 32 semanas, mínimo de dez dias de vida, sistema visual e auditivos sem alterações detectadas e hospitalizados na Unidade Mãe-Canguru. A amostra foi randomizada por sorteio em dois grupos, com 31 prematuros submetidos à estimulação multimodal com música, diariamente, durante sete dias, comparados com 30 prematuros que receberam apenas estimulação multimodal. Foram avaliadas as características dos prematuros, além de ganho de peso, consumo energético, frequência cardíaca e respiratória, sinais de estresse e forma de alimentação. A comparação entre os grupos foi realizada pelos testes $t$ de Student, Mann Whitney e qui-quadrado, sendo significante $p<0,05$.

Resultados: Os grupos não mostraram diferença significante em relação à forma de alimentação e ao consumo energético $(p=0,46)$, porém o ganho de peso foi maior no Grupo Experimental ( $p=0,002)$, que também apresentou maior estabilidade das frequências cardíaca e respiratória $(p<0,001)$ e redução dos sinais de estresse $(p=0,007)$, comparado ao Grupo Controle.

\author{
Endereço para correspondência: \\ Olga Maria S. Amancio \\ Rua Botucatu, 703 \\ CEP 04023-062 - São Paulo/SP \\ E-mail: omsamancio.dped@epm.br \\ Conflito de interesse: nada a declarar
}

Recebido em: 22/6/2012

Aprovado em: 14/2/2013 
Conclusões: A música associada à estimulação multimodal é eficaz para maior ganho de peso corporal de prematuros hospitalizados e tem influência positiva sobre os sinais vitais e de estresse (Registro de Ensaios Clínicos - UTN: U1111-1153-9301).

Palavras-chave: música; peso corporal; prematuro; terapia combinada.

\section{RESUMEN}

Objetivo: Evaluar el efecto de la música grabada con estimulación modal sobre la ganancia de peso en prematuros incluidos en el Programa Madre-Canguro.

Métodos: Ensayo clínico randomizado con 61 prematuros, de ambos sexos, con edad postconcepcional superior o igual a 32 semanas, mínimo de 10 días de vida, sistema visual y auditivos sin alteraciones detectadas y hospitalizados en la Unidad MadreCanguro. La muestra fue randomizada por sorteo en dos grupos, con 31 prematuros sometidos a la estimulación multimodal con música, diariamente, durante siete días, comparados con 30 prematuros que recibieron solamente estimulación multimodal. Se evaluaron las características de los prematuros, además de ganancia de peso, consumo energético, frecuencia cardíaca y respiratoria, señales de estrés y forma de alimentación. La comparación entre los grupos fue realizada por las pruebas $t$ de Student, Mann Whitney y chi-cuadrado, conforme a la naturaleza de las variables, siendo significante $p<0,05$.

Resultados: Los grupos no mostraron diferencia significante respecto a la forma de alimentación y al consumo energético $(p=0,46)$, pero la ganancia de peso fue mayor en el Grupo Experimental $(p=0,002)$, que también presentó la estabilidad mayor de las frecuencias cardíaca y respiratoria $(p<0,01)$ y reducción de las señales de estrés $(p=0,007)$ significantes respecto al Grupo Control.

Conclusiones: La música grabada asociada a la estimulación multimodal es eficaz para mayor ganancia de peso corporal de prematuros hospitalizados y tiene influencia positiva sobre las señales vitales y de estrés.

Palabras clave: música; peso corporal; prematuro; terapia combinada.

\section{Introduction}

The constant technological development in neonatal intensive care, associated with obstetric advances, led to a decrease in the mortality rate of premature newborns, enhancing their survival rates. Among the surviving children, one can find increasing proportions of premature infants with gestational ages considered at risk for the occurrence of a variety of developmental dysfunctions ${ }^{(1)}$.

Knowing that, after the $25^{\text {th }}$ week of gestation, the premature infant already responds to auditory stimuli ${ }^{(2)}$, music could be used as a therapeutic resource, when adopted with criteria and with the appropriate noise level ${ }^{(3)}$. Music stimulus may be employed in isolation or associated with another technique such as multimodal stimulation, enhancing its effects and leading to a more holistic care ${ }^{(4)}$. Music, with its elements, sounds, rhythms, melody and harmony, works as an intermediate object of a relationship that enables the development of a therapeutic process $^{(4)}$. Thus, the basic acoustics of music may influence both physiological and behavioral aspects of the individual ${ }^{(5)}$. Studies with premature infants report its influence on the reduction in heart and respiratory rates, cortisol levels, and behavioral states of stress, with an increase in oxygen saturation, in the velocity of non-nutritive sucking, and in weight gain, thus reducing hospitalization time ${ }^{(5-7)}$. A systematic review reports that, generally speaking, music may be beneficial for premature infants in behavioral terms, but has inconsistent results regarding physiological aspects, with studies limited by the heterogeneity of the samples and of methodological aspects ${ }^{(7)}$.

There are few studies analyzing the influence of music on weight gain. The hypothesis would be that premature infants exposed to music could have their weight gain increased, but the mechanisms of this effect are little known, requiring randomized studies. The length of hospital stay of premature infants is directly related to their clinical stability and velocity of weight gain. Assuming that techniques such as music and multimodal stimulation may influence physiological aspects such as weight gain, and being aware of the lack of investigations on this topic, the present study aimed to evaluate, at the end of seven days of treatment, the effect of music with com multimodal stimulation on the weight gain of premature infants with postconceptional age greater than or equal to 32 weeks included in the Kangaroo-Mother Program.

\section{Method}

A randomized clinical trial was conducted with 61 hospitalized premature infants, of both genders, divided into two groups through simple randomization by draw in sealed envelopes, with 31 in the Experimental Group, which underwent music therapy and multimodal stimulation, and 30 in the Control Group, which underwent only multimodal stimulation. This project was not submitted to clinicaltrial.gov. The study period 
lasted from November 2008 to March 2009, and the setting was Maternidade-Escola Santa Mônica, located in Maceió, state of Alagoas, Northeastern Brazil, a referral center for high-risk pregnant women and newborns of the public Unified Health System in the state. The study was approved by the Clinical Board of Directors of the maternity hospital and by the Ethics Committee of the Universidade Federal de São Paulo, with the need of previous written consent from parents or guardians.

The Kangaroo Method is a type of neonatal care comprising three stages, with skin-to-skin contact between mother and low birth weight newborn and increasing duration, for the time that both of them understand as pleasant ${ }^{(2)}$. The kangaroo position consists of maintaining the low birth weight newborn in a prone position against the chest of the adult $t^{(2)}$. The study was conducted at the second stage of the Kangaroo-Mother Program at the Maternidade-Escola Santa Mônica, which has a capacity of 12 beds. This phase takes place at a rooming-in facility, i.e., all children and their mothers share the same space, and mothers are identically advised by the same team on breastfeeding and kangaroo position. At this stage, children should be clinically stable, with total enteral nutrition, and may be continuously accompanied by their mother, who should be prepared for this at an early stage ${ }^{(2)}$.

The eligible premature infants had a postconceptional age $\geq 32$ weeks $^{(8)}$ and at least ten days of life ${ }^{(8)}$. Their hearing was evaluated by bilaterally evoked otoacoustic emissions ${ }^{(2)}$ and their vision by ophthalmoscopy, performed by the ophthalmologist responsible for the patients of the unit ${ }^{(2)}$. The study excluded premature infants diagnosed with severe hypoxia, intracranial hemorrhage, pulmonary, cardiac or neurological problems, as well as malformations, syndromes, and the presence of clinical complications during the study period, such as signs of respiratory distress, diarrhea or gastroesophageal reflux disease.

The recorded music was played in the background, consisting of soft classical songs with low range, simple and direct rhythm, such as those by Mozart ${ }^{(5,6)}$. The songs varied during the course of sessions, using the same variation for each child in the Experimental Group.

As for multimodal stimulation, the therapist remained seated, and the premature infant remained in the supine position on his or her lap. Before the beginning of stimulation, the premature infant was positioned in physiological flexion, for better body organization ${ }^{(10)}$. Multimodal stimulation occurred in the following order: tactile, vestibular, and visual ${ }^{(10)}$. Tactile stimulation was performed through the touch of the therapist by massaging the limbs in the proximal to distal direction and the trunk in the cephalocaudal direction, with slow and continuous stroking ${ }^{(11)}$.
For vestibular stimulation, the child was placed on a hammock made from a sheet in the supine position and was slowly lifted up to the semi-seated position; then the child was lowered again to the supine position ${ }^{(9)}$. Visual stimulation used cards with highly-contrasting colors, i.e., black and white. The card was positioned at a distance of $20 \mathrm{~cm}$ from the child's face, observing if there was visual fixation when the card was standing still and if there was visual tracking was the card was moving ${ }^{(12)}$. Each type of stimulation lasted for five minutes, with a total of 15 minutes ${ }^{(8)}$. The procedures were performed by the same therapist in all children. The study period comprised seven consecutive days of a week, in the afternoon period.

The therapy environment was calm, with controlled lighting and noise level controlled by sound level meter in $55 \mathrm{~dB}^{(13)}$ at the place where the child was being treated. The treatment was conducted in a silent room, located in the kangaroo nursery, respecting the period after nutrition and sleep, and the child should be in the behavioral state of inactive alertness to receive the stimulation. In inactive alertness, which is the best state for interaction, child's body and face are relatively inactive, their eyes are shiny and their breathing is regular ${ }^{(2)}$. In the routine practice of the service, feeding occurs every two or three hours for feeding via orogastric tube and complementary feeding; breastfeeding occurs on demand. Weighting takes place at 05.30 a.m.

The Experimental Group received multimodal stimulation with background music, and the Control Group received only multimodal stimulation. In the Experimental Group, music was initially used in isolation for 1 minute and then a sequence of multimodal stimulation - tactile, vestibular and visual was conducted with music ${ }^{(10)}$. In the Control Group, the same sequence of multimodal stimulation was performed, but without music. The order of stimuli was always the same for both groups.

The following characteristics of the premature infants were collected: gender, mode of delivery (cesarean or normal), gestational age estimated by the Capurro method (weeks), postconceptional age (weeks), $1^{\text {st }}$ and $5^{\text {th }}$ minute Apgar score, birth weight (g) weight at the beginning of the study ( $\mathrm{g}$ ), days of life at the beginning of the study (days), and ICU length of stay (days).

Outcome variables were:

- Body weight: assessed daily using a duly calibrated C\&F weighting scale, mod.p15, with a $5 \mathrm{~g}$ division, analyzing the mean for body weight gain between the first and the seventh day;

- Stress signs: their presence or absence during each treatment session in premature infants in response to handling was recorded. A presence-to-absence ratio of stress signs was built in all days of treatment for each group, making a comparison 
between groups. Stress signs included the presence of one or more grimaces, yawns, hiccups, and crying ${ }^{(2)}$. Stress sigs were always recorded by the same observer, in both groups. These signs were previously detailed, and the observer was trained to identify them.

- Heart and respiratory rates: were assessed immediately before (HR 1 and RR1) and immediately after (HR2 and RR2) the treatment session, calculating the difference between the two occasions (HR1-HR2 and RR1-RR2). The mean of these differences for the seven days of treatment was compared between the two groups, Control and Experimental. These vital signs were evaluated by a one-minute inspection through auscultation with a stethoscope.

- Feeding method: the use of the methods orogastric tube, complementary feeding, and breastfeeding was evaluated. Complementary diet included translactation, breastfeeding associated with orogastric tube, and breastfeeding associated with cup feeding.

- Energy consumption (kJ/day): the calculation of energy consumption took into account feeding method, volume, daily frequency, and type of milk (Pre-Nan or breast milk). For Pre-Nan milk, a value of $334.9 \mathrm{~kJ}$ per $100 \mathrm{~mL}$ was estimated ${ }^{(14)}$ and, for breast milk, of $242.8 \mathrm{~kJ}$ per $100 \mathrm{~mL}^{(15)}$. For breastfed premature infants, volume was estimated by gastric capacity in approximately $40 \mathrm{~mL}^{(16)}$. In exclusive breastfeeding, frequency was every three hours, totaling eight feedings, which is the minimum required for the mothers in the unit under study.

Sample calculation was based on a pilot study with 20 premature infants. The observed outcome was weight gain: $110 \pm 50 \mathrm{~g}$ in the Control Group and 150 $41 \mathrm{~g}$ in the Experimental Group. Considering an alpha error of 0.05 and a beta error of 0.90 , it was found that each group should be composed of 29 subjects.

Data were stored and tabulated on a Microsoft Excel ${ }^{\circledR} 2003$ spreadsheet. The applications Statistical Package For Social Sciences (SPSS), version 15.0, and Epi-Info, version 6.04, were used. Sample homogeneity was investigated by the Kolgomorov-Smirnov test. Comparison between the characteristics of the patients (weight, ICU length of stay, gestational age, among others) in the two groups was made by Student $t$ test, Mann Whitney test, and chi-square test, according to the nature of the variables. Significance was set at $p<0.05$.

\section{Results}

With regard to the characteristics of the premature infants under study, there was no difference between the two groups in terms of gender distribution in each group ( $p=0.91)$, mode of delivery - cesarean or normal $(p=1.00)$, gestational age $(p=0.54)$, postconceptional age $(p=0.54), 1^{\text {st }}$ minute Apgar score $(p=0.72)$, $5^{\text {th }}$ minute Apgar score $(p=0.97)$, birth weight $(p=0.09)$, weight $(p=0.73)$, days of life at the beginning of the study $(p=0.53)$, and ICU length of stay $(p=0.06)$ (Table 1).

At the beginning of the study, body weight in the Experimental Group showed no difference compared with that in the Control Group. On the other hand, throughout the seven days of treatment, weight gain was significantly greater in the Experimental Group ( $p=0.002$ ) (Table 1). Despite the difference in weight gain between the two groups during the treatment period, energy consumption in this period showed no significant difference $(p=0.46$ ) (Table 2 ). The groups did not also show significant difference in relation to feeding method $(p=0.414)($ Graph 1).

The premature infants in the Experimental Group showed lower presence-to-absence ratio of stress signs $(p=0.007)$ during treatment sessions (Table 3). Heart and respiratory rates showed significant decrease after treatment in the Experimental Group, compared with the Control Group $(p<0.001)$ (Table 4). These parameters remained within normal limits during treatment sessions in both groups.

\section{Discussion}

Unimodal and multimodal sensory stimulation were analyzed in several studies and have their benefits already documented, including those related to weight gain $^{(10,11)}$. On the other hand, the benefits of music as auditory stimulation have only recently been recognized and scientifically documented ${ }^{(7)}$. Music may enhance the effects of multimodal stimulation, and one of its advantages would be promoting homeostasis, which facilitates child's tolerance to stimuli ${ }^{(4)}$.

In this study, the results for body weight gain showed that premature infants in the Experimental Group had a significantly greater mean than that of infants in the Control Group, which is extremely important for premature infants, since weight gain is directly related to clinical stability and lower length of hospital stay. It is worth stressing that the evaluated groups did not show significant difference in terms of feeding methods and mean energy consumption. Thus, one of the hypotheses suggested for weight gain in the Experimental Group is that, in children fed orally, music may improve appetite and improve the sucking/swallowing mechanism ${ }^{(5)}$. Some studies evaluated the association of music with non-nutritive sucking and reported that, during music, there is an increase in feeding 
rates. However, the authors do not clarify whether children had previous experience with oral feeding, since this information may influence feeding rate $e^{(17,18)}$. Another mechanism that could influence weight gain was proposed by a study that evaluated the relationship between music by Mozart and resting energy expenditure by indirect calorimetry in premature infants. The results indicated a reduction of $10-13 \%$ in resting energy expenditure in the group evaluated with music, which could increase metabolic efficiency and partly increase weight gain ${ }^{(6)}$. In this paper, the results for body weight related to the influence of music are in accordance with results from other investigations $^{(19,20)}$. A study used music with multimodal stimulation and compared its use with a control group undergoing only the routine procedure of the unit. Its result was significant in terms of weight gain by the experimental group, but this study does not report the feeding method or the energy consumption of premature infants ${ }^{(8)}$. Differences in methodology, inclusion criteria, and feeding methods may result in disagreements between studies.

The early adaptation to extrauterine life exposes the premature infant to a greater number of stressful situations, resulting in physiological changes, increase in energy requirements, and difficulty in gaining weight. During painful procedures, the positive effect of music has been reported due to its influence in the gate mechanism of pain and in the increase in endorphin release ${ }^{(21,22)}$. More stable children are more prone to gain weight ${ }^{(3)}$. The results for this research in terms of reduction in stress signs confirm

Table 1 - Characteristics of premature infants in Control and Experimental Groups during the study period

\begin{tabular}{|c|c|c|c|}
\hline & $\begin{array}{c}\text { Control } \\
n=30\end{array}$ & $\begin{array}{c}\text { Experimental } \\
n=31\end{array}$ & $p$-value \\
\hline Male: female gender & $10: 20$ & $12: 19$ & 0.913 \\
\hline Cesarean: normal delivery & $14: 16$ & $15: 16$ & 1.00 \\
\hline Gestational age (weeks) & $\begin{array}{c}32 \pm 2 \\
(29-34)\end{array}$ & $\begin{array}{c}32 \pm 2 \\
(29-34)\end{array}$ & 0.536 \\
\hline Postconceptional age (weeks) & $\begin{array}{c}36 \pm 2 \\
(32-39)\end{array}$ & $\begin{array}{c}35 \pm 2 \\
(32-42)\end{array}$ & 0.536 \\
\hline Birth weight $(\mathrm{g})$ & $\begin{array}{c}1494 \pm 279 \\
(915-2145)\end{array}$ & $\begin{array}{c}1374 \pm 271 \\
(805-1630)\end{array}$ & 0.092 \\
\hline Weight at the beginning of the study $(\mathrm{g})$ & $\begin{array}{c}1557 \pm 108 \\
(1250-1910)\end{array}$ & $\begin{array}{c}1541 \pm 108 \\
(1250-2000)\end{array}$ & 0.731 \\
\hline $1^{\text {st }}$ minute Apgar score & $\begin{array}{l}7 \pm 2 \\
(2-9)\end{array}$ & $\begin{array}{l}7 \pm 2 \\
(2-9)\end{array}$ & 0.721 \\
\hline $5^{\text {th }}$ minute Apgar score & $\begin{array}{c}9 \pm 1 \\
(7-10)\end{array}$ & $\begin{array}{c}9 \pm 1 \\
(5-10)\end{array}$ & 0.970 \\
\hline Days of life at the beginning of the study & $\begin{array}{c}22 \pm 14 \\
(10-56)\end{array}$ & $\begin{array}{c}24 \pm 15 \\
(10-69)\end{array}$ & 0.529 \\
\hline ICU length of stay (days) & $\begin{array}{c}15 \pm 1 \\
(2-56)\end{array}$ & $\begin{array}{l}21 \pm 16 \\
(3-69)\end{array}$ & 0.060 \\
\hline
\end{tabular}

Intervals in parentheses indicate the variation in the values found

Table 2 - Means for body weight gain and energy consumption among premature infants in Control and Experimental groups during the study period

\begin{tabular}{lccc}
\hline & $\begin{array}{c}\text { Control } \\
\mathbf{n}=\mathbf{3 0}\end{array}$ & $\begin{array}{c}\text { Experimental } \\
\mathbf{n}=\mathbf{3 1}\end{array}$ & $\boldsymbol{p}$-value \\
\hline Energy consumption (kcal/day) & $219 \pm 73$ & $208 \pm 46$ & 0.46 \\
\hline Body weight gain $(\mathrm{g})$ & $(72-378)$ & $(93-378)$ & $156 \pm 46$ \\
$(-70-225)$ & $(60-240)$ & 0.002 \\
\hline
\end{tabular}

Intervals in parentheses indicate the variation in the values found 


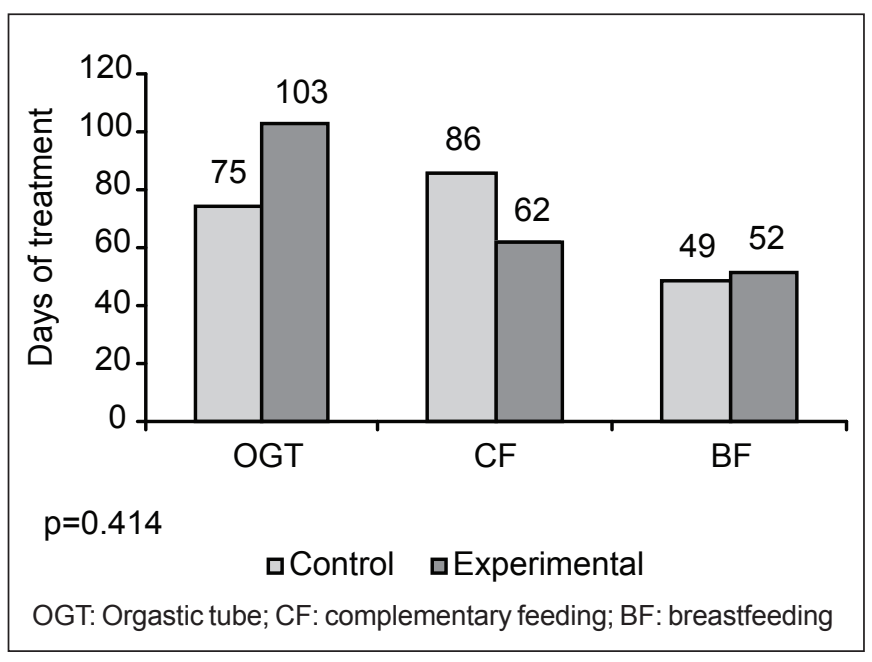

Graph 1 - Distribution of feeding methods: orogastric tube, complementary feeding, and breastfeeding in control and experimental groups

Table 3 - Presence-to-absence ratio of stress signs during treatment among premature infants in Control and Experimental groups

\begin{tabular}{lccc}
\hline $\begin{array}{l}\text { Stress } \\
\text { signs }\end{array}$ & $\begin{array}{c}\text { Control } \\
\mathbf{n}=\mathbf{3 0}\end{array}$ & $\begin{array}{c}\text { Experimental } \\
\mathbf{n}=\mathbf{3 1}\end{array}$ & $\boldsymbol{p}$-value \\
\hline $\begin{array}{l}\text { Presence- } \\
\text { to-absence }\end{array}$ & $\begin{array}{c}0.28 \pm 0.47 \\
(0.00-2.50)\end{array}$ & $\begin{array}{c}0.07 \pm 0.1 \\
(0.00-0.40)\end{array}$ & 0.007 \\
ratio & 0 & \\
\hline
\end{tabular}

Intervals in parentheses indicate the variation in the values found

Table 4 - Comparison of the difference in heart rates and respiratory rates before (1) and after (2) treatment between Control and Experimental groups

\begin{tabular}{|c|c|c|c|}
\hline & $\begin{array}{c}\text { Control } \\
n=30\end{array}$ & $\begin{array}{c}\text { Experimental } \\
n=31\end{array}$ & $p$-value \\
\hline HR1-HR2 & $\begin{array}{c}1.4 \pm 2.5 \\
(-3.7-6.6)\end{array}$ & $\begin{array}{c}16.9 \pm 8.7 \\
(2.3-37.1)\end{array}$ & $<0.001$ \\
\hline RR1-RR2 & $\begin{array}{c}0.9 \pm 2.4 \\
(-2.3-7.7)\end{array}$ & $\begin{array}{c}9.1 \pm 3.1 \\
(0.9-16.1)\end{array}$ & $<0.001$ \\
\hline
\end{tabular}

HR: heart rates; RR: respiratory rates; Intervals in parentheses indicate the variation in the values found

previous results ${ }^{(4,20)}$. A study reported a significant reduction in cortisol levels and in respiratory rate among premature infants exposed to live music with harp ${ }^{(23)}$. Another study indicates a significant reduction in stress signs and physiological parameters ${ }^{(24)}$. This result may be justified by the fact that the study investigated a group of premature infants with chronic lung diseases who have clinical peculiarities different from those analyzed in the present study.

As for heart and respiratory rates, the Experimental Group showed significant decrease after the procedure. Several studies show similar results for respiratory ${ }^{(23)}$ and heart ${ }^{(3,21)}$ rate. One of the justifications for these results is that music seems to reduce the activity of the sympathetic nervous system ${ }^{(25)}$.

Thus, music may be used as simple, alternative and low cost therapeutic tool, constituting one more agent aiming to facilitate the development of premature infants and minimize the negative effects of neonatal admission. Although mothers and children were admitted in the same setting, receiving similar recommendations from the same team, there are variables that are difficult to control, such as the time children remain in the kangaroo position and the exact number of feedings. As a limitation of this study, it is possible to point out the inaccuracy in the calculation of energy consumption, because this is directly dependent on the physiological characteristics of each child and on the variation in the energy content of the breast milk of each mother. In spite of this limitation, the values stipulated for this calculation were equally adopted in both groups; thus, it can be said that the difference found would not be in function of energy consumption but rather of the only distinctive factor between the groups, i.e., exposure to music. The paper also has methodological restrictions, because it was a non-blind study for some variables such as vital and stress signs. In addition, it is worth remembering that, although observers had been trained for the correct application of the technique, there is the individualized response of each child, not ruling out the possibility of some side effect related to hyperstimulation.

Still due to the lack and limitations of investigations on music as a therapeutic method in premature infants, there are questions to be answered, such as its long-term effects, the different musical styles along with individual preferences, as well as its influence on the family and the multi-professional team. Anyway, the results obtained suggest that recorded music, associated with multimodal stimulation, is efficient for a greater weight gain of premature infants hospitalized in the Mother-Kangaroo Program.

\section{Acknowledgments}

Thanks to the premature infants and their families, to all the team from the Mother-Kangaroo Program of MaternidadeEscola Santa Mônica, to the study advisor, the study co-advisor, and to the physical therapist Ana Lúcia Gusmão Freire. 


\section{References}

1. Mancini MC, Paixão ML, Silva TT. Comparação das habilidades motoras de crianças prematuras e crianças nascidas a termo. Rev Fisioter Univ Sao Paulo 2000;7:25-3.

2. Brasil. Ministério da Saúde. Atenção humanizada ao recém-nascido de baixopeso: método mãe canguru (Série A. Normas e Manuais Técnicos, $n^{\circ} 145$ ). Brasília: Ministério da Saúde; 2009.

3. Andriola YM, Oliveira BR. A Influência da música na recuperação do recémnascido prematuro na UTI neonatal. Nursing 2006;8:973-8.

4. Standley JM. Music therapy for neonate. Newborn Infant Nurs Rev 2001;1:211-6.

5. Standley JM. A meta-analysis of the efficacy of music therapy for premature infants. J Pediatr Nurs 2002;17:107-13.

6. Lubetzky R, Mimouni FB, Dollberg S, Reifen R, Ashbel G, Mandel D. Effect of music by Mozart on energy expenditure in growing preterm infants. Pediatrics 2010;125:e24-8.

7. Hartling L, Shaik MS, Tjosvold L, Leicht R, Liang Y, Kumar M. Music for medical indications in neonatal period: a systematic review of randomised controlled trials. Arch Dis Child Fetal Neonatal Ed 2009;94:F349-54.

8. Standley JM. The effect of music and multimodal stimulation on responses of premature infants in neonatal intensive care. Pediatr Nurs 1998;24:532-54.

9. White-Traut RC, Nelson MN, Silvestri JM, Vasan U, Littau S, Meleedy-Rey $\mathrm{P}$ et al. Effect of auditory, tactile, visual, and vestibular intervention on length of stay, alertness, and feeding progression in preterm infants. Dev Med Child Neurol 2002;44:91-7.

10. Ferreira AM, Bergamasco NH. Behavioral analysis of preterm neonates included in a tactile and kinesthetic stimulation program during hospitalization. Rev Bras Fisioter 2010;14:141-8.

11. Tecklin JS. A criança de alto risco. In: Tecklin JS, editor. Fisioterapia pediátrica. $3^{\text {rd }}$ ed. São Paulo: Artmed; 2002. p. 69-96.

12. Cardoso MV, Silva GR. Visual evaluation in the child: from the neonatal unity to the domicile. Rev RENE 2004:5:68-74.
13. Autoria não referida. Noise: a hazard for the fetus and newborn. American Academy of Pediatrics. Committee on Environmental Health. Pediatrics 1997; $100: 724-7$

14. Bulário: bulas de medicamentos [homepage on the Internet]. Bula de Pre Nan [cited 2010 Jan 20]. Available from: http://bulario.net/pre_nan/

15. Euclydes MP. Aleitamento materno. In: Euclydes MP, editor. Nutrição do lactente. $2^{\text {nd }}$ ed. Minas Gerais: Suprema; 2000. p. 261-2.

16. Giugliani ER, Victora CG. Normas alimentares para crianças brasileiras menores de dois anos: embasamento científico. Brasília: OMS/OPAS; 1997.

17. Standley JM. The effect of contingent music to increase non-nutritive sucking of premature infants. Pediatr Nurs 2000;26:493-5.

18. Standley JM. The effect of music-reinforced nonnutritive sucking on feeding rate of premature infants. J Pediatr Nurs 2003;18:169-73.

19. Caine J. The effects of music on the selected stress behaviors, weight, caloric and formula intake, and length of hospital stay of premature and low birth weight neonates in a newborn intensive care unit. J Music Ther 1991;28:180-92.

20. Coleman JM, Pratt RR, Stoddard, RA, Gerstmann DR, Abel HH. The effects of the male and female singing and speaking voices on selected physiological and behavioral measures of premature infants in the intensive care unit. Int J Arts Med 1997;5:4-11.

21. Bo LK, Callaghan P. Soothing pain-elicited distress in Chinese neonates. Pediatrics 2000;105:E49.

22. Butt ML, Kisilevsky BS. Music modulates behaviour of premature infants following heel lance. Can J Nurs Res 2000;31:17-39.

23. Block $S$, Jennings $D$, David L. Live harp music decreases salivary cortisol levels in convalescent preterm infants. Pediatr Res 2003;53:469A.

24. Shoemark H, Wolfe R, Calabro J. The effects of recorded sedative music on the physiology and behaviour of premature infants with a respiratory disorder. Aust J Music Ther 2003;14:3-19.

25. Todres ID. Music is medicine for the heart. J Pediatr (Rio J) 2006;82:166-8. 